\title{
Impact of home and community-based services on hospitalisation and institutionalisation among individuals eligible for long-term care insurance in Japan
}

Naoki Tomita, Kimio Yoshimura* and Naoki Ikegami

\begin{abstract}
Background: This population-based retrospective cohort study aimed to clarify the impact of home and community-based services on the hospitalisation and institutionalisation of individuals certified as eligible for longterm care insurance (LTCI) benefits.

Methods: Health insurance data and LTCI data were combined into a database of 1,020 individuals in two farming communities in Hokkaido who were enrolled in Citizen's Health Insurance. They had not received long-term care services prior to April 1, 2000 and were newly certified as eligible for Long-Term Care Insurance benefits between April 1, 2000 and February 29, 2008. The analysis covered 565 subjects who had not been hospitalised or institutionalised at the time of first certification of LTCI benefits. The adjusted hazard ratios (HRs) of hospitalisation or institutionalisation or death after the initial certification were calculated using the Cox proportional hazard model. The predictors were age, sex, eligibility level, area of residence, income, year of initial certification and average monthly outpatient medical expenditures, in addition to average monthly total home and communitybased services expenditures (analysis 1), the use or no use of each type of service (analysis 2), and average monthly expenditures for home-visit and day-care types of services, the use or no use of respite care, and the use or no use of rental services for assistive devices (analysis 3).

Results: Users of home and community-based services were less likely than non-users to be hospitalised or institutionalised. Among the types of services, users of respite care (HR: 0.71, 95\% confidence interval [Cl]: 0.55-0.93) and rental services for assistive devices (HR: $0.70,95 \% \mathrm{Cl}$ : 0.54-0.92) were less likely to be hospitalised or institutionalised than non-users. For those with relatively light needs, users of day care were also less likely to be hospitalised or institutionalized than non-users (HR: 0.77, 95\% Cl: 0.61-0.98).

Conclusions: Respite care, rental services for assistive devices and day care are effective in preventing hospitalisation and institutionalisation. Our results suggest that home and community-based services contribute to the goal of the LTCl system of encouraging individuals certified as needing long-term care to live independently at home for as long as possible.
\end{abstract}

\section{Background}

The social costs of hospitalisation and institutionalisation are growing [1-3], and the majority of elderly people would prefer to stay in their own homes, even if they have a serious disability [4]. Extending the period

\footnotetext{
* Correspondence: kyoshimu@sc.itc.keio.ac.jp

* Correspondence: kyoshimu@sc.itc.keio.ac.jp
Department of Health Policy \& Management, Keio University School of Medicine, Tokyo, JAPAN
}

(c) 2010 Tomita et al; licensee BioMed Central Ltd. This is an Open Access article distributed under the terms of the Creative Commons Attribution License (http://creativecommons.org/licenses/by/2.0), which permits unrestricted use, distribution, and reproduction in any medium, provided the original work is properly cited. thus become a very important issue. Japan's public longterm care insurance (LTCI) system was introduced in April 2000 from this perspective. LTCI, by making it easier for individuals certified as needing long-term care to use home and community-based services, aims to prevent decline of functional level and allow elderly people to live independently in their homes for as long as 
possible [5]. Hospitalisation or institutionalisation would therefore be an adverse event. Although hospitalisation is for providing medical services and institutionalisation is for providing long-term care services, for frail elderly it is difficult to distinguish between the two. This is especially the case in Japan, where admissions to hospitals are frequently made for social reasons-no family member to provide care or long waiting lists for nursing homes [6-8].

Hospitalisation and institutionalisation have been used as outcome measures to observe the impact of preventive interventions such as education, counselling, and assessment in various countries [9-17], but studies on the effects of home and community-based services have been limited. In Japan, the preventive effect of day care on institutionalisation was reported before the introduction of LTCI $[18,19]$. Following the introduction of LTCI, outcomes have focused not on admissions, but on changes in eligibility levels [20-24], moreover, these studies did not adjust either for the use of medical services or for medical condition. Reports in other countries include the effect of home-help for the elderly with dementia [25], and that of day care [26,27] or that of respite services combining day care and respite care [28], but these studies were confined to institutionalisation and did not include hospitalisation. On the other hand, $\mathrm{Xu}$ et al. [29] showed that a greater volume of attendant care, homemaking services and home-delivered meals was associated with a lower risk of hospitalisation. In this study, we decided to focus on the impact of home and community-based services on hospitalisation and institutionalisation after adjusting for the use of medical services by using health insurance data and LTCI data from a small community. Specifically, we selected as outcome admission to a hospital or a longterm care institution after being certified as eligible for LTCI benefits. Additional subgroup analyses were made in order to confirm whether home and communitybased services are beneficial for older adults with only light care needs as suggested by previous studies $[20,22,24]$. Our sample was limited to a small community because national databases do not exist, and linkage of health insurance and LTCI data was only possible in the area studied.

\section{Methods}

Public long-term care insurance system

Japan's LTCI is compulsory for all citizens $\geq 40$ years of age, and those who are eligible for its benefits are individuals aged $\geq 65$ years who require long-term care as well as individuals aged 40-65 years who require longterm care for diseases related to ageing. It is managed by municipal government. Certification of eligibility and determination of the level of benefits are based on a nationally standardised assessment process. When the LTCI system was introduced, six eligibility levels were established: "Support level", in which assistance is needed, and "Care levels 1, 2, 3, 4 and 5", in which care is needed, with 1 being the lightest and 5 being the heaviest. These levels are primarily determined by a computerised algorithm that is based on the responses to the questionnaire on current physical and mental status (74 items). This algorithm was derived from a statistical analysis of care time and subjects' clinical characteristics. The levels grouped by the algorithm do not correspond to clinical prototypes. The final decision is made by a local committee of specialists (physicians, social workers and so forth), who take into consideration a report from the attending physician and 12 quantitative aspects focused mainly on behaviour [30,31]. In April 2006, the LTCI system was revised to seven levels, with the Support level reset as "Support level 1" and the majority in "Care level 1" regrouped to "Support level 2" [31,32]. Certification of long-term care benefits is made without consideration of the willingness and ability of the individual's family or friends to provide care, or the individual's income. Benefits are provided not as cash but as home and community-based or institutional services, with recipients paying $10 \%$ of the care cost $[33,34]$.

\section{Health insurance}

Enrolling in health insurance is mandatory for all residents in Japan [30]. Employees, together with their dependents, are enrolled in employees' health insurance, while the self-employed, people living on pensions, and others are enrolled in Citizen's Health Insurance (CHI), which is managed by municipalities [35]. Therefore, the majority of elderly people are enrolled in CHI [35]. The proportion of the population aged 70 and above who are enrolled in CHI nationally was $82.3 \%$ in 2006 [36,37]. In the area of the present study the figure was $80.5 \%$. Most people aged $\geq 70$ years pay $10 \%$ of medical charges as copayment.

\section{Study area}

This study was conducted in two farming communities (Towns A and B) located in central Hokkaido, which is in the north of Japan. This area is becoming increasingly depopulated and there is a lack of public transportation.

Table 1 provides basic data for the study area, Hokkaido, and all of Japan, for the years 2001 and 2007. It includes the population [38,39], the proportion of the aged 65 and above [38,39], the proportion of the population aged 70 and above who are enrolled in CHI (2006 only) $[36,37]$, the average monthly expenditures per individual enrolled under the medical care for the elderly program $[40,41]$, the proportion of the individuals certified as being eligible for LTCI benefits among 
Table 1 Characteristics of study site, Hokkaido and all of Japan

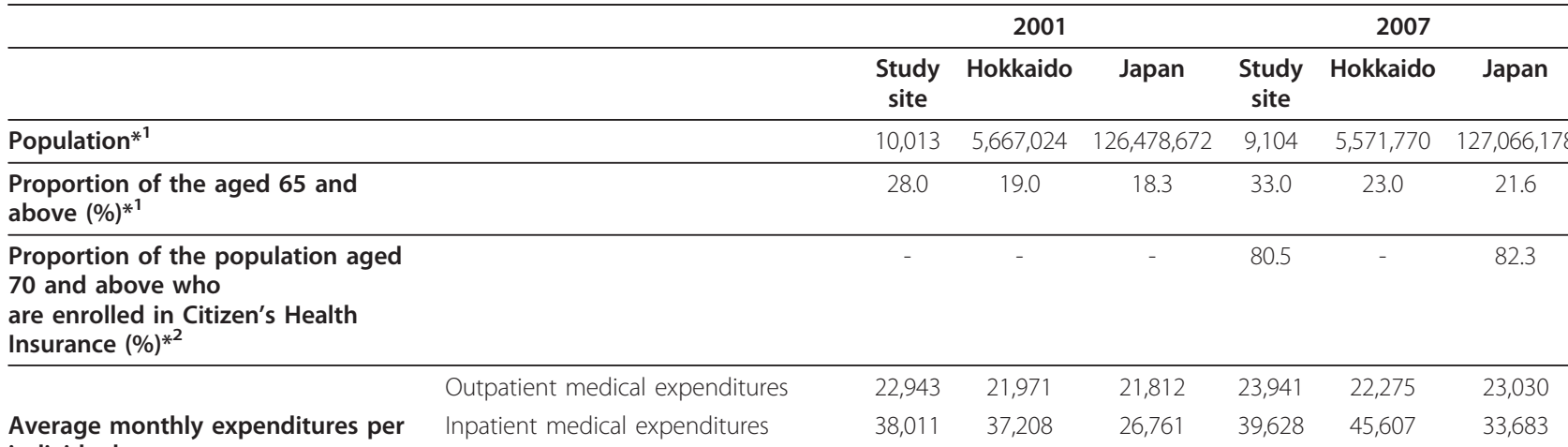

individual

enrolled under the medical care for

the

elderly program (yen)*3

\begin{tabular}{|c|c|c|c|c|c|c|c|}
\hline & Total medical expenditures & 60,954 & 59,179 & 48,573 & 63,568 & 67,882 & 56,713 \\
\hline & Support level*6 & $\begin{array}{c}2.7 \\
(21.0)\end{array}$ & $1.9(14.0)$ & $1.7(13.1)$ & $\begin{array}{c}3.4 \\
(18.3)\end{array}$ & $2.1(12.2)$ & $2.0(12.2)$ \\
\hline & Care level $1^{* 7}$ & $\begin{array}{c}3.5 \\
(26.4)\end{array}$ & $4.3(32.0)$ & $3.8(29.3)$ & $\begin{array}{c}4.6 \\
(24.8)\end{array}$ & $5.8(34.0)$ & $5.1(30.8)$ \\
\hline $\begin{array}{l}\text { Proportion of the individuals } \\
\text { certified as } \\
\text { being eligible for LTCI benefits } \\
\text { among }\end{array}$ & Care level 2 & $\begin{array}{c}2.4 \\
(18.0)\end{array}$ & $2.5(18.6)$ & $2.4(18.9)$ & $\begin{array}{c}3.0 \\
(16.3)\end{array}$ & $2.9(17.2)$ & $2.9(17.7)$ \\
\hline \multirow{13}{*}{$\begin{array}{l}\text { individuals aged } \geq 65 \text { years } \\
\text { according to } \\
\text { each eligibility level }(\%) \text { and its } \\
\text { distribution }(\%)^{* 4}\end{array}$} & Care level 3 & $\begin{array}{c}1.6 \\
(12.3)\end{array}$ & $1.5(11.4)$ & $1.7(13.0)$ & $\begin{array}{c}2.6 \\
(13.9)\end{array}$ & $2.4(14.3)$ & $2.6(15.6)$ \\
\hline & Care level 4 & $\begin{array}{c}1.5 \\
(11.7)\end{array}$ & $1.5(11.4)$ & $1.7(13.0)$ & $\begin{array}{c}2.1 \\
(11.4)\end{array}$ & $1.9(11.1)$ & $2.1(12.7)$ \\
\hline & Care level 5 & $\begin{array}{c}1.4 \\
(10.6) \\
\end{array}$ & $1.7(12.6)$ & $1.6(12.7)$ & $\begin{array}{c}2.8 \\
(15.4)\end{array}$ & $1.9(11.2)$ & $1.8(11.0)$ \\
\hline & Total & $\begin{array}{c}13.1 \\
(100) \\
\end{array}$ & $13.3(100)$ & $12.9(100)$ & $\begin{array}{c}18.4 \\
(100) \\
\end{array}$ & $17.0(100)$ & $16.5(100)$ \\
\hline & $\begin{array}{l}\text { Total amount of home and } \\
\text { community-based services }\end{array}$ & 36,017 & 42,190 & 46,870 & 35,042 & 42,383 & 49,018 \\
\hline & Total amount of institutional services & 295,525 & 360,799 & 347,202 & 266,367 & 270,556 & 269,441 \\
\hline & $\begin{array}{l}\text { Total amount of long-term care } \\
\text { services }\end{array}$ & 144,532 & 123,423 & 109,802 & 103,139 & 98,776 & 90,554 \\
\hline & \multicolumn{7}{|l|}{ Home and community-based services } \\
\hline & Home-help ${ }^{* 8}$ & 31,490 & 45,164 & 53,396 & 40,300 & 40,805 & 48,866 \\
\hline & Home-visit bathing ${ }^{* 9}$ & 0 & 45,376 & 48,715 & 44,962 & 52,359 & 56,356 \\
\hline & Visiting nurse ${ }^{* 9}$ & 43,964 & 37,240 & 42,223 & 24,264 & 37,751 & 41,867 \\
\hline & Visiting rehabilitation*9 & $\mathrm{n} / \mathrm{a}$ & 21,277 & 21,470 & $\mathrm{n} / \mathrm{a}$ & 24,276 & 25,264 \\
\hline & Management \& guidance ${ }^{* 9}$ & 13,651 & 10,098 & 9,773 & 10,882 & 9,229 & 10,067 \\
\hline $\begin{array}{l}\text { Average monthly expenditures per } \\
\text { recipient }\end{array}$ & Day care ${ }^{* 10}$ & 35,261 & 42,566 & 52,608 & 34,242 & 53,142 & 67,279 \\
\hline \multirow[t]{7}{*}{ of specific care service (yen) ${ }^{* 5}$} & Day rehabilitation*9 & 39,469 & 57,469 & 68,512 & 36,577 & 58,584 & 67,341 \\
\hline & Respite care ${ }^{* 11}$ & 106,800 & 93,959 & 83,162 & 80,232 & 82,583 & 87,963 \\
\hline & Rental services for assistive devices ${ }^{* 9}$ & 12,359 & 13,461 & 14,349 & 12,202 & 12,163 & 14,858 \\
\hline & $\begin{array}{l}\text { Small scale community-based multiple } \\
\text { services centres }{ }^{* 9}\end{array}$ & $\mathrm{n} / \mathrm{a}$ & $\mathrm{n} / \mathrm{a}$ & $\mathrm{n} / \mathrm{a}$ & $\mathrm{n} / \mathrm{a}$ & 168,732 & 173,167 \\
\hline & \multicolumn{7}{|l|}{ Institutional services } \\
\hline & $\begin{array}{l}\text { Group homes for the elderly with } \\
\text { dementia*12 }\end{array}$ & 0 & 239,865 & 238,750 & 253,656 & 261,843 & 262,342 \\
\hline & $\begin{array}{l}\text { Residential care facilities for the } \\
\text { elderly requiring care }{ }^{* 13}\end{array}$ & 189,171 & 157,917 & 185,640 & 146,515 & 153,129 & 176,692 \\
\hline
\end{tabular}




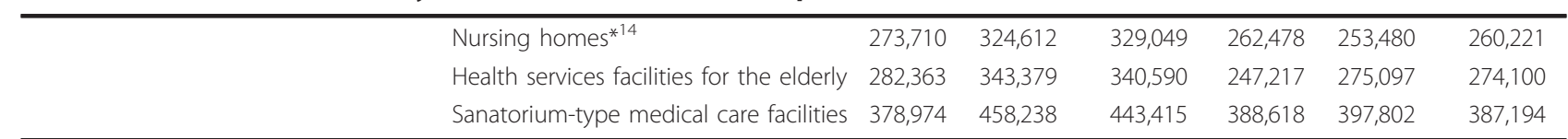

*1 Data from Japan Geographic Data Center, "Jyumin Kihon Daicho Jinko Yoran (Population summary of basic residents' register)" at the end of the each fiscal year.

*2 Proportion of the population aged 70 and above who are enrolled in Citizen's Health Insurance (\%) = The population of the Citizen's Health Insurance member aged 70 and above / The total population of the persons aged 70 and above. Data at the end of the fiscal year 2006 is used.

*3 Data from All-Japan Federation of National Health Insurance Organizations, "Kokumin-Kenko-Hoken no Jittai (Situation of Citizen's Health Insurance)". Data for study site, Hokkaido and Japan for 2002 is substituted for those for 2001. Data for "Sorachi Chubu Koiki Rengo", which includes study site, is substituted for the study site.

*4 Proportion of the individuals certified as being eligible for LTCI benefits among individuals aged $\geq 65$ years (\%) = the number of the all aged individuals certified as long-term care / the number of the insured individuals aged 65 and above. Data for Hokkaido and Japan from Japan Ministry of Health, Labour and Welfare, "Report on the Status of the Long-term Care Insurance Project" at the end of the each fiscal year.

*5 Data for study site for 2007 excludes March 2008. Data for Hokkaido and Japan from Japan Ministry of Health, Labour and Welfare, Ministry Secretariat, Statistics and Information Department, "Survey of Long-term Care benefit Expenditures". Data for Hokkaido for 2002 is substituted for that for 2001.

*6 Support level for 2007 means Support level 1.

*7 Care level 1 for 2007 includes Support level 2.

*8 "Preventive care" and "Night care" are included for 2007.

*9 "Preventive care" is included for 2007.

*10 "Preventive care" and "Services for the elderly with dementia" are included for 2007.

*11 Consists of regular and medically-related Respite care. "Preventive care" is included for 2007.

*12 Counted as institutional services in this study. "Preventive care" is included for 2007.

*13 Counted as institutional services in this study. "Preventive care" and "Community-based residential care facilities for the elderly requiring care" are included for 2007.

*14 "Community-based welfare facilities for the elderly requiring care" are included for 2007.

All years are fiscal years; April to March.

individuals aged $\geq 65$ years according to each eligibility level $[42,43]$, and average monthly expenditures per recipient of specific care service [44-46].

Compared with the national average, the percentage of elderly people in this area was high. Outpatient medical expenditures per individual enrolled under the medical care for the elderly program were about the same level, but inpatient medical expenditures were higher. The proportion of Support level certification was higher, but the Care level was about the same as for the nation. The home and community-based and institutional services expenditures per recipient of long-term care were lower.

\section{Subjects (Figure 1)}

The subjects were drawn from a total of 1,020 individuals who were enrolled in the Citizen's Health Insurance in the study area, who had not been receiving long-term care services prior to April 1, 2000, and had been newly certified as eligible for LTCI benefits between April 1, 2000 (when LTCI was implemented), and February 29, 2008. Of the total, 432 who were hospitalised or institutionalised at the time of their first certification were excluded in order to standardise the base-line characteristics. The average eligibility level of those who were already hospitalised or institutionalised at the time of the first eligibility certification was 2.03 and significantly higher than 0.87 for those who were living in the community (the lowest eligibility level being 0 , the highest 5 ). Twenty-three who did not have data for their income level were also excluded. The remaining 565 people were analysed. The sample had to be limited to those enrolled in the Citizen's Health Insurance program, which enrolls $80.5 \%$ of the population 70 and over, because record linkage with LTCI was only possible for this group.

\section{Preparation of data set}

For all 1,020 subjects, information on long-term care services and medical services for each month from April

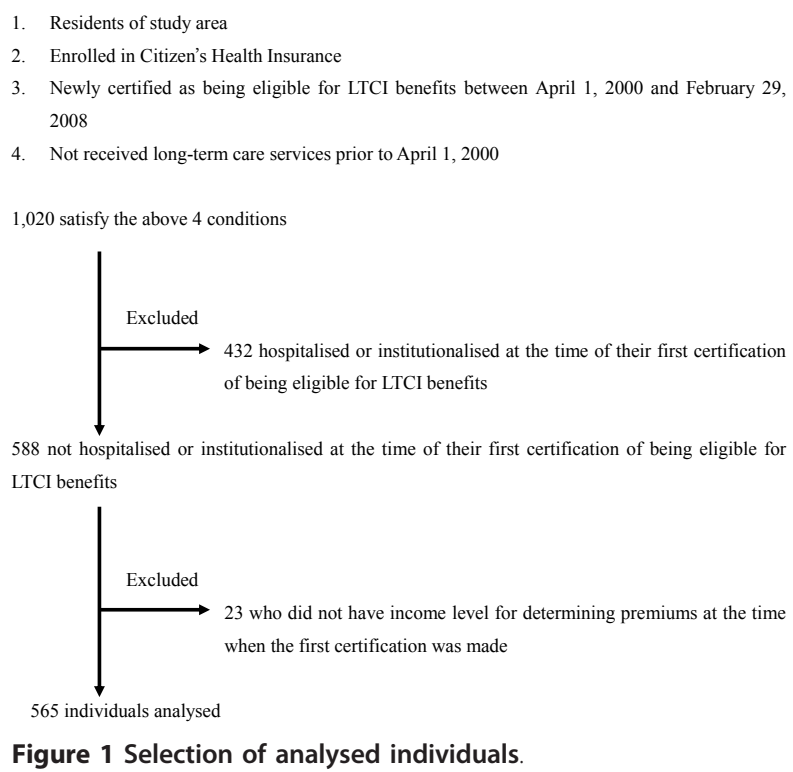


1, 2000 to February 29, 2008 was collected from the claims data of LTCI and Citizen's Health Insurance. The records for the two datasets were linked for each individual.

The information on long-term care services included sex, month and year of birth, start/end date of eligibility, eligibility level, date of death/removal, long-term care services code, month and year when long-term care services were provided, long-term care services claims amount, and LTCI premium amounts (based on income level).

The information on medical services was residential code (Town A or B); monthly medical care services claims amount for hospitalisation, outpatient care, dental care, dispensary, visiting nurse, and osteopathic therapy; and the dates of hospital admission and discharge.

\section{Measures \\ Outcome variable}

The outcome variable was the number of months from the first certification of being eligible for LTCI benefits until the occurrence of an "event" or censoring. Events were hospitalisation, institutionalisation or death from the initial certification up until February 29, 2008. Death was included as an event because it is the worst adverse outcome and excluding deaths at home would bias the sample. In cases when there were no events by February 29,2008 , censoring was done at that time, or at the time the subject moved out of the area. "Hospitalisation" refers to being admitted to a hospital; "institutionalisation" to being admitted to a nursing home, health services facility for the elderly, or sanatorium-type medical care facility. Admission to group homes for the elderly with dementia and residential care facilities for the elderly requiring care, which administratively are defined as community-based care, were nearly all for the longterm, and were therefore included in "institutionalisation". Threshold expenditure amounts (i.e. 100,000 yen for the initial month, about $\$ 1,200$ at the current exchange rate of US\$1 = ¥82) were set for "hospitalisation" and "institutionalisation" in order to eliminate short episodes such as for examinations or treatment of mild trauma.

\section{Predictor variables}

The main predictor variables were the use of home and community-based services and of medical services. These variables were constructed from expenditure data in the following way.

Average monthly expenditures were calculated for outpatient medical expenditures, total home and community-based services expenditures, and expenditures for home-visit and day-care types of services, respectively. The cumulative amounts of outpatient medical expenditures, total home and community-based services expenditures, and expenditures for home-visit and daycare types of services for each analysed individual from certification until hospitalisation, institutionalisation, death or censoring were divided by the number of months and converted to the amount per month. "Outpatient medical expenditures" are the total for outpatient medical expenditures, dental expenditures, visiting nurse expenditures (when billed to health insurance), medication expenditures, and osteopathic therapy expenditures, calculated from their monthly claims amount. Total home and community-based services expenditures, and expenditures for home-visit and daycare types of services are calculated from the claims amount for the corresponding type of service. The detail of long-term care services included in all home and community-based services and home-visit and day-care types of services are shown in the tables and their legends.

Average monthly outpatient medical expenditures were divided into three levels: low, medium, and high. Non-users are included in the low expenditure group because Japanese tend to visit physicians for minor complaints [47]; thus their basic characteristics are likely to be substantively the same as non-users. Divisions into levels were calculated so that the number of subjects in each was equal. However, for LTCI services, non-users were grouped into a separate level because they may have a different rationale for undergoing the certification process if they subsequently had not used any services. The users group was divided equally into three levels of low, medium, and high expenditures.

Use or no use was recorded for each of the home and community-based services: home-help (including homevisit bathing), visiting nurse, management and guidance, day care, day rehabilitation, respite care and rental services for assistive devices. Services were considered to be used when they were billed and paid. In the study area, two services-visiting rehabilitation and small scale communitybased multiple services centres-were not available.

\section{Demographic variables}

The demographic variables of sex, age, eligibility level for LTCI, area of residence, income level for determining LTCI premiums at time of the first certification of long-term care benefits, and year of the first certification were also taken as predictor variables. In this study, in order to maintain consistency in eligibility levels from April 1, 2000 to February 29, 2008, Support level 1 continued to be counted as Support level, but Support level 2 was grouped with Care level 1 after April 1, 2006, when the number of levels was increased from six to seven. These six levels were then combined into the three levels of Support level, Care levels 1 and 2, and Care levels 3 to 5 in order to have sufficient numbers for each level. 


\section{Statistical analysis}

Main analysis To calculate a hazard ratio for hospitalisation and institutionalisation using a Cox proportional hazard model, three analyses were carried out.

The outcome was the time to hospitalisation, institutionalisation or death from the time of the first certification of being eligible for LTCI benefits. In order to investigate the overall effect of home and communitybased services (Analysis 1), the sex, age and eligibility level at time of the first certification of long-term care benefits were entered in a model as predictor variables. The other predictor variables were selected from the area of residence and income level at time of the first certification of long-term care benefits, the year of the first certification, outpatient medical expenditures and total home and community-based services expenditures by using a forward stepwise method. Variables were entered in a model if $\mathrm{p}<0.05$ and removed from a model if they became $\mathrm{p}>0.10$.

To observe the effects for each type of home and community-based service, a similar analysis (Analysis 2) was done with use or no use of each type of service replacing average monthly total home and communitybased services expenditures in Analysis 1.

To observe the effects of home-visit and day-care types of services, respite care, and rental services for assistive devices, a similar analysis (Analysis 3 ) was made in which average monthly expenditures for home-visit and daycare types of services, use or no use of respite care and rental services for assistive devices were used as predictor variables, replacing average monthly total home and community-based services expenditures in Analysis 1.

Subgroup analysis Analysis 2 was made with only individuals certified as needing long-term care of Support level or Care levels 1 or 2 (individuals certified as having light need for long-term care). This analysis was made because in some previous studies [20,22,24], observations of the effect of each home and community-based service on eligibility level were limited to individuals certified as having light need for long-term care.

The statistical software package SPSS Statistics Ver. 17.0 was used in the analysis.

\section{Ethical considerations}

The data used in this study were provided by the insurer as linkable anonymous data from which personal information had been removed. This study was reviewed and approved by the ethics committee of the Keio University School of Medicine.

\section{Results}

\section{Characteristics of subjects}

The descriptive statistics of the outcome variable and predictor variables are shown in Tables 2 and 3 . The mean age (years) \pm standard deviation at the time of the first certification was $81.4 \pm 6.7$. The median was 82.0 (range 61.8-98.1). Among all the analysed individuals, 99.3\% were $\geq 65$ years old, and 91.9\% were in Support level or Care level 1 or 2 (Table 2).

The average monthly outpatient medical expenditure per analysed individual was 57,004 yen, with a median value of 36,807 yen (Table 3). For the mid-level expenditure, the amount was 24,000-53,000 yen (Table 2). The national average for those in the medical care for the elderly program was about $22,000-23,000$ yen in 2001 and 2007 (Table 1). Because the individuals analysed had been certified as being eligible for LTCI benefits, their average monthly outpatient medical expenditures were likely to be higher than that of the national level.

The average monthly total home and community-based services expenditure per analysed individual was 25,560 yen, with a median value of 15,657 yen (Table 3 ). The mid-level amount was 18,000-36,000 yen (Table 2) which was less than the national average per recipient of home and community-based services, which was between 47,000 and 49,000 yen in 2001 and 2007 (Table 1).

\section{Predictors of admission to hospital or long-term care institution or death Main analysis (Table 4)}

The results of the analysis using a Cox proportional hazard model are shown in Table 4 (the results of Analysis 3 are essentially the same as those of Analysis 2, and so they are not shown).

In Analysis 1, there tended to be more hospitalisation or institutionalisation in men than in women, in those aged $\geq 80$ years than $<75$ years, and in those with Care levels from 3 to 5 than Support level (HR: 1.77, 95\% CI: 1.20-2.61). The residents of Town B were less likely to be hospitalised or institutionalised than the residents of Town A (HR: 0.80, 95\% CI: 0.65-0.997). Those who were first certified later were less likely to be hospitalised or institutionalised (HR: 0.95, 95\% CI: 0.90-0.99). The group with high average monthly outpatient medical expenditures was more likely to be hospitalised or institutionalised than the low expenditure group (HR: 2.14, 95\% CI: $1.66-2.75)$. For average monthly total home and community-based services expenditures, the low expenditure (HR: 0.70, 95\% CI: 0.53-0.93) and midlevel expenditure (HR: 0.59, 95\% CI: 0.44-0.79) and high expenditure (HR: 0.72, 95\%CI: 0.54-0.96) groups were all less likely to be hospitalised or institutionalised than the home and community-based services non-users group. No other predictor variables were selected.

In Analysis 2, the result was similar to that in Analysis 1 except for a greater tendency for hospitalisation or institutionalisation in Care level from 1 to 5 than in 
Table 2 Cohort characteristics $(\mathrm{N}=565)$

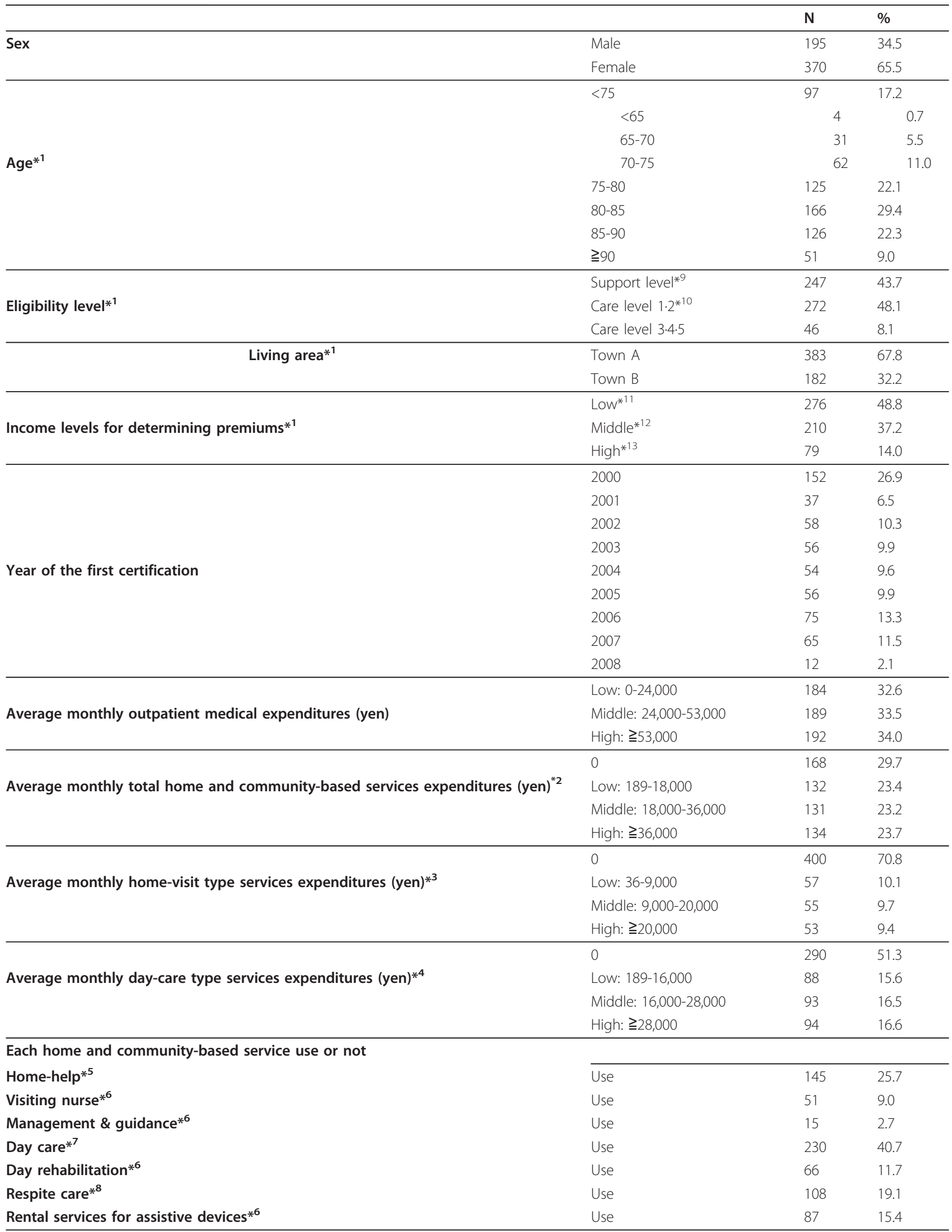


Table 2 Cohort characteristics $(\mathrm{N}=565)$ (Continued)

Outcome

Censor

\begin{tabular}{lll}
\hline No event before 29 Feb.2008 & 155 & 27.4 \\
Move out & 4 & 0.7 \\
\hline Subtotal & 159 & 28.1 \\
\hline Hospitalisation & 327 & 57.9 \\
Institutionalisation & 55 & 9.7 \\
Death & 24 & 4.2 \\
\hline Subtotal & 406 & 71.9
\end{tabular}

*1 Data when the insured person is certified as being eligible for long-term care insurance benefits for the first time.

*2 Consists of expenditures of Home-help, Home-visit bathing, Visiting nurse, Management \& guidance, Day care, Day rehabilitation, Respite care and Rental service for assistive devices.

*3 Consists of expenditures of Home-help, Home-visit bathing, Visiting nurse and Management \& guidance.

*4 Consists of expenditures of Day care and Day rehabilitation.

*5 Includes Home-visit bathing. After 2006, "Preventive care" and "Night care" are included.

*6 After 2006, "Preventive care" is included.

*7 After 2006, "Preventive care" and "Services for the elderly with dementia" are included.

*8 Consists of regular and medically-related Respite care. After 2006, "Preventive care" is included.

*9 After 2006, Support level means Support level 1.

*10 After 2006, Care level 1 includes Support level 2.

*11 Both individual and household exempt from community tax.

*12 Individual exempt from community tax, household pays community tax.

*13 Individual pays community tax.

All years are fiscal years; April to March.

Support level. Hospitalisation and institutionalisation were less likely among users of respite care than nonusers (HR: 0.71, 95\% CI: 0.55-0.93), and among users of rental services for assistive devices than non-users (HR: 0.70, 95\% CI: 0.54-0.92). Day care was selected, but was not statistically significant. No other predictor variables were selected.

The results of Analysis 3 were the same as those for Analysis 2.

Subgroup analysis (limited to individuals certified as having light need for long-term care)

For each home and community-based service, users of day care had fewer hospitalisations or institutionalisations than non-users (HR: 0.77, 95\% CI: 0.61-0.98, p = 0.032). The results for other predictor variables were the same as in Analysis 2 of the main analysis.

\section{Discussion}

We studied the impact of home and community-based services on hospitalisation and institutionalisation of individuals certified as being eligible for LTCI benefits for the first time following the introduction of public LTCI. The presence of a disease and its severity at the time of the first certification could be confounding factors, since they could lead to the hospitalisation or institutionalisation of the subject $[11,15,48-58]$. In our study, we took this factor into consideration by adjusting for outpatient medical expenditures, which would serve as an indicator of the severity of illness. The group with high average monthly outpatient medical expenditures was more likely than the low expenditure group to be hospitalised or institutionalised. This result and the results of demographic variables were reasonable.

Table 3 Descriptive statistics of outcome and expenditure variables $(\mathrm{N}=565)$

\begin{tabular}{|c|c|c|c|c|c|}
\hline & mean & mediam & standard devation & maximum & minimum \\
\hline Observation period (months) ${ }^{* 1}$ & 19.5 & 13.2 & 20.1 & 94.9 & 0.03 \\
\hline \multicolumn{6}{|l|}{ Average monthly expenditures (yen) } \\
\hline Outpatient medical services & 57,004 & 36,807 & 97,462 & $1,152,831$ & 0 \\
\hline Total home and community-based services ${ }^{* 2}$ & 25,560 & 15,657 & 34,637 & 255,009 & 0 \\
\hline Home-visit type services ${ }^{* 3}$ & 8,002 & 0 & 23,682 & 210,097 & 0 \\
\hline Day-care type services ${ }^{* 4}$ & 12,041 & 0 & 17,780 & 127,506 & 0 \\
\hline
\end{tabular}

*1 Time to hospitalisation, institutionalisation, death or censoring from the first certification of being eligible for long-term care insurance benefits.

*2 Consists of Home-help, Home-visit bathing, Visiting nurse, Management \& guidance, Day care, Day rehabilitation, Respite care and Rental services for assistive devices.

*3 Consists of Home-help, Home-visit bathing, Visiting nurse and Management \& guidance.

*4 Consists of Day care and Day rehabilitation. 
Table 4 Adjusted hazard ratio (HR) and 95\% confidence interval (Cl) for admission to hospital or long-term care institution or death $(\mathrm{N}=565)$

\begin{tabular}{|c|c|c|c|c|c|c|c|}
\hline \multicolumn{4}{|c|}{ Analysis 1: The overall effect of home and community-based services } & \multicolumn{4}{|c|}{$\begin{array}{l}\text { Analysis 2: The effects of each type of home and } \\
\text { community-based service }\end{array}$} \\
\hline & $\begin{array}{l}\text { Adjusted } \\
\text { HR }\end{array}$ & $95 \% \mathrm{Cl}$ & $\begin{array}{c}\mathrm{p}- \\
\text { value }\end{array}$ & & $\begin{array}{l}\text { Adjusted } \\
\text { HR }\end{array}$ & $95 \% \mathrm{Cl}$ & $\begin{array}{c}p- \\
\text { value }\end{array}$ \\
\hline Sex & & & 0.007 & Sex & & & 0.006 \\
\hline Male & 1 & & & Male & 1 & & \\
\hline Female & 0.749 & $\begin{array}{l}0.607- \\
0.924\end{array}$ & & Female & 0.742 & $\begin{array}{l}0.600- \\
0.917 \\
\end{array}$ & \\
\hline Age $^{* 1}$ & & & 0.003 & Age $^{* 1}$ & & & 0.001 \\
\hline$<75$ & 1 & & & $<75$ & 1 & & \\
\hline $75-80$ & 1.237 & $\begin{array}{l}0.893- \\
1.713\end{array}$ & 0.201 & $75-80$ & 1.231 & $\begin{array}{l}0.884- \\
1.715\end{array}$ & 0.219 \\
\hline $80-85$ & 1.406 & $\begin{array}{l}1.023- \\
1.934\end{array}$ & 0.036 & $80-85$ & 1.436 & $\begin{array}{l}1.035- \\
1.991\end{array}$ & 0.030 \\
\hline $85-90$ & 1.435 & $\begin{array}{l}1.041- \\
1.979\end{array}$ & 0.027 & $85-90$ & 1.526 & $\begin{array}{l}1.103- \\
2.111\end{array}$ & 0.011 \\
\hline$\geqq 90$ & 2.168 & $\begin{array}{l}1.464- \\
3.212 \\
\end{array}$ & 0.000 & $\geqq 90$ & 2.261 & $\begin{array}{l}1.514- \\
3.378 \\
\end{array}$ & 0.000 \\
\hline Eligibility level*1 & & & 0.014 & Eligibility level*1 & & & 0.000 \\
\hline Support level*2 & 1 & & & Support level*2 & 1 & & \\
\hline Care level $1 \cdot 2^{* 3}$ & 1.177 & $\begin{array}{l}0.946- \\
1.465\end{array}$ & 0.143 & Care level $1 \cdot 2^{* 3}$ & 1.314 & $\begin{array}{l}1.057- \\
1.634\end{array}$ & 0.014 \\
\hline Care level $3.4 \cdot 5$ & 1.769 & $\begin{array}{l}1.199- \\
2.611 \\
\end{array}$ & 0.004 & Care level 3.4 .5 & 2.154 & $\begin{array}{l}1.450- \\
3.199 \\
\end{array}$ & 0.000 \\
\hline Living area ${ }^{* 1}$ & & & 0.047 & Living area*1 & & & 0.045 \\
\hline Town A & 1 & & & Town A & 1 & & \\
\hline Town B & 0.804 & $\begin{array}{l}0.648- \\
0.997\end{array}$ & & Town B & 0.801 & $\begin{array}{l}0.645- \\
0.995\end{array}$ & \\
\hline Year of the first certification & 0.946 & $\begin{array}{l}0.902- \\
0.992\end{array}$ & 0.022 & Year of the first certification & 0.942 & $\begin{array}{l}0.900- \\
0.986\end{array}$ & 0.011 \\
\hline Income level for determining premiums*1 & & $\begin{array}{c}\text { Not } \\
\text { Selected }\end{array}$ & & $\begin{array}{l}\text { Income level for determining } \\
\text { premiums*1 }\end{array}$ & & $\begin{array}{c}\text { Not } \\
\text { Selected }\end{array}$ & \\
\hline $\begin{array}{l}\text { Average monthly outpatient medical } \\
\text { expenditures (yen) }\end{array}$ & & & 0.000 & $\begin{array}{l}\text { Average monthly outpatient } \\
\text { medical expenditures (yen) }\end{array}$ & & & 0.000 \\
\hline Low: 0 - 24,000 & 1 & & & Low: 0 - 24,000 & 1 & & \\
\hline Middle: $24,000-53,000$ & 1.226 & $\begin{array}{l}0.947- \\
1.587\end{array}$ & 0.122 & Middle: $24,000-53,000$ & 1.191 & $\begin{array}{l}0.920- \\
1.542\end{array}$ & 0.185 \\
\hline High: $\geqq 53,000$ & 2.138 & $\begin{array}{l}1.663- \\
2.749 \\
\end{array}$ & 0.000 & High: $\geqq 53,000$ & 2.149 & $\begin{array}{l}1.668- \\
2.769\end{array}$ & 0.000 \\
\hline $\begin{array}{l}\text { Average monthly total home and community- } \\
\text { based services expenditures (yen) } \text { * }^{4}\end{array}$ & & & 0.005 & Day care ${ }^{* 5}$ & & & 0.088 \\
\hline 0 & 1 & & & Not use & 1 & & \\
\hline Low: $189-18,000$ & 0.700 & $\begin{array}{l}0.526- \\
0.931\end{array}$ & 0.014 & Use & 0.821 & $\begin{array}{l}0.655- \\
1.029\end{array}$ & \\
\hline Middle: 18,000 - 36,000 & 0.587 & $\begin{array}{l}0.436- \\
0.791\end{array}$ & 0.000 & Respite care ${ }^{* 6}$ & & & 0.013 \\
\hline \multirow[t]{6}{*}{ High: $\geqq 36,000$} & 0.722 & $\begin{array}{l}0.542- \\
0.960 \\
\end{array}$ & 0.025 & Not use & 1 & & \\
\hline & \multicolumn{3}{|c|}{$\begin{array}{l}\text { Akaike' s Information } \\
\text { Criteria(AIC) }=4434.401\end{array}$} & Use & 0.714 & $\begin{array}{l}0.547- \\
0.931 \\
\end{array}$ & \\
\hline & & & & \multicolumn{2}{|c|}{ Rental services for assistive devices ${ }^{*^{7}}$} & & 0.011 \\
\hline & & & & Not use & 1 & & \\
\hline & & & & Use & 0.703 & $\begin{array}{l}0.537- \\
0.921\end{array}$ & \\
\hline & & & & Home-help* & & $\begin{array}{c}\text { Not } \\
\text { Selected }\end{array}$ & \\
\hline
\end{tabular}




\begin{tabular}{|c|c|}
\hline Visiting nurse $\mathrm{*}^{7^{7}}$ & $\begin{array}{c}\text { Not } \\
\text { Selected }\end{array}$ \\
\hline Management \& guidance ${ }^{*^{7}}$ & $\begin{array}{c}\text { Not } \\
\text { Selected }\end{array}$ \\
\hline Day rehabilitation ${ }^{* 7}$ & $\begin{array}{c}\text { Not } \\
\text { Selected }\end{array}$ \\
\hline
\end{tabular}

Outcome variable was the number of months from the first certification of being eligible for long-term care insurance benefits until hospitalisation, institutionalisation, death or censoring in both Analysis 1 and 2. All years are fiscal years; April to March.

*1 Data when the insured individuals are certified being eligible for long-term care insurance benefits for the first time.

*2 After 2006, Support level means Support level 1.

*3 After 2006, Care level 1 includes Support level 2.

*4 Consists of expenditures of Home-help, Home-visit bathing, Visiting nurse, Management \& guidance, Day care, Day rehabilitation, Respite care and Rental services for assistive devices.

*5 After 2006, "Preventive care" and "Services for the elderly with dementia" are included.

*6 Consists of regular and medically-related Respite care. After 2006, "Preventive care" is included.

*7 After 2006, "Preventive care" is included.

*8 Includes Home-visit bathing service. After 2006, "Preventive care" and "Night care" are included.

Those who used home and community-based services, and respite care and rental services for assistive devices in particular, were less likely than non-users to be hospitalised or institutionalised. Thus, the policy objectives of LTCI appear to have been met especially for those using these services. Regarding assistive devices, Tajika et al. had reported that among individuals certified as having light need for long-term care, users of rental services for assistive devices tend to show a greater decline in eligibility level than non-users [20]. This observation was used to support the removal of rental services for wheel-chairs, motorised beds and other devices that might induce disuse syndrome from LTCI benefits for those in the lighter eligibility levels in 2007 . However, our study shows that they had a beneficial effect, perhaps because the negative effect of some devices was less than the positive effect of using canes and walking aids which prevent decline. This indicates a need to differentiate among devices. For day care, when the subjects are limited to individuals certified as having light need for long-term care, a positive effect was seen, which supports the 2007 LTCI revision that promoted these services.

Two possible mechanisms may explain the effects of home and community-based services in preventing hospitalisation and institutionalisation. One is that home and community-based services prevent a decline in the physical and mental state of individuals certified as needing long-term care (prevention of decline) [14] and the other is that these services reduce the care burden of caregivers, allowing them to maintain their ability to provide care (maintenance of caregivers' ability) $[26,59,60]$. The effect of respite care could mainly be attributed to the latter [24,26,59-61], and not to the former [24,62]. Assistive devices, if used appropriately, should have the former effect $[14,63]$. The effect of day care among individuals certified as having light need for long-term care could be either maintenance of caregivers' ability $[26,59,60,64,65]$, prevention of decline of physical and mental functions [14,22,65-68], or both.

\section{Limitations}

The population studied was limited to those enrolled in the CHI, composing $80.5 \%$ of the total, and to those who had been certified as eligible for LTCI. Those who had not been certified were not included but this was unavoidable from the study design. Those who had moved outside of the two municipalities could not be followedup, but they composed only $0.7 \%$ of the total. Among those in the sample, the data on service use should be complete because they were from the claims forms.

Average monthly expenditures for home and community-based services tended to increase somewhat as the time from the first certification elapsed, with the amount being $¥ 15,400$ for the first three months and $¥ 21,800$ for the last three months. This factor was not considered when making our analysis. However, since the difference between the two remained within the ranges of the three levels of expenditures and the hazard ratios for the three levels were almost the same (0.7), the magnitude of these changes are not likely to have impacted on our results.

Since this study was a retrospective cohort study, and not a randomised controlled trial, we could not verify any causal relationships. The possibility that the results were biased by residual and unmeasured confounding cannot be entirely ruled out. 
The presence or absence of family members living with the individual who may provide support, and their caregiving ability, have been reported to have an impact on decline $[69,70]$ and on hospitalisation and institutionalisation $[26,52,60,71,72]$. These factors could not be analysed in our study because the data were not available, but they should be included in future studies.

Our study was conducted in farming communities in one region of Japan and it should be replicated in urban communities and other regions.

\section{Conclusions}

In this study, the impact of home and community-based services on hospitalisation and institutionalisation of individuals certified as being eligible for LTCI benefits for the first time was analysed after adjusting for demographic variables and outpatient medical expenditures. The results showed that users of home and communitybased services were less likely than non-users to be hospitalised or institutionalised. Among the types of home and community-based services, users of respite care and rental services for assistive devices were less likely to be hospitalised or institutionalised than non-users. When subjects were limited to individuals certified as having light need for long-term care, hospitalisation and institutionalisation were also less likely for users of day care than for non-users. Therefore, respite care, rental services for assistive devices and day care were effective in preventing hospitalisation and institutionalisation. Our results suggest home and community-based services contribute to the goal of the LTCI system of encouraging individuals certified as being eligible for LTCI benefits to live independently at home for as long as possible.

\section{Abbreviations}

LTCl: long-term care insurance; HR: hazard ratio; Cl: confidence interval; CHI: Citizen's Health Insurance.

\section{Acknowledgements}

This study is partly supported by the Japanese Ministry of Health, Labour and Welfare (National Institute of Population and Social Security Research Grant number H19-seisaku-ippan-021) and Health Labour Science Research Grant (Grant number H14-seisaku-022).

The authors express their sincere appreciation to all those in the study area who provided information on public LTCI and health insurance and Chikako Igarashi, MA, of the Hokkaido Intellect Tank, and to John Creighton Campbell, PhD, Yasuo Takagi, BA, Keita Yamauchi, MD, PhD, Tomoaki Ishibashi, MA, Sumie Ikezaki, MSc, and Ayumi Igarashi, PhD, for their insightful comments.

\section{Authors' contributions}

NT, KY and NI developed the original idea for this study. NT extracted the data, performed the statistical analysis and wrote the original manuscript. KY and $\mathrm{NI}$ provided supervision during the entire process. All authors have read and approved final manuscript.

\section{Competing interests}

The authors declare that they have no competing interests.
Received: 17 June 2010 Accepted: 22 December 2010

Published: 22 December 2010

\section{References}

1. Tsuji I, Kuwahara A, Nishino Y, Ohkubo T, Sasaki A, Hisamichi S: Medical cost for disability: a longitudinal observation of national health insurance beneficiaries in Japan. J Am Geriatr Soc 1999, 47(4):470-476.

2. Rice DP, Fox PJ, Max W, Webber PA, Lindeman DA, Hauck WW, Segura E: The economic burden of Alzheimer's disease care. Health Aff (Millwood) 1993, 12(2):164-176.

3. Leon J, Cheng CK, Neumann PJ: Alzheimer's disease care: costs and potential savings. Health Aff (Millwood) 1998, 17(6):206-216.

4. Salvage AV, Jones DA, Vetter NJ: Opinions of people aged over 75 years on private and local authority residential care. Age Ageing 1989, 18(6):380-386.

5. Long-term Care Insurance Research Council: Kaigo-hoken Roppo (The Long-term Care Insurance Laws). Chuohoki 2008.

6. Japan Society for Healthcare Administration: Iryo Byoin Kanri Yogo Jiten (Dictionary of Healthcare and Hospital Administration Terms: 3rd revised edition). Elsevier Japan; 2006.

7. Japan Health and Welfare Statistics Association: Kokumin Eisei no Doko (Trends of National Hygiene in Japan). Japan Health and Welfare Statistics Association; 2009.

8. Ikegami N, Yamauchi K, Yamada Y: The long term care insurance law in Japan: impact on institutional care facilities. Int J Geriatr Psychiatry 2003, 18(3):217-221.

9. Beswick AD, Rees K, Dieppe P, Ayis S, Gooberman-Hill R, Horwood J, Ebrahim S: Complex interventions to improve physical function and maintain independent living in elderly people: a systematic review and meta-analysis. Lancet 2008, 371(9614):725-735.

10. Vass $M$, Avlund $K$, Hendriksen $C$ : Randomized intervention trial on preventive home visits to older people: baseline and follow-up characteristics of participants and non-participants. Scand J Public Health 2007, 35(4):410-417.

11. Stuck AE, Egger M, Hammer A, Minder CE, Beck JC: Home visits to prevent nursing home admission and functional decline in elderly people: systematic review and meta-regression analysis. JAMA 2002, 287(8):1022-1028.

12. Elkan R, Kendrick D, Dewey M, Hewitt M, Robinson J, Blair M, Williams D, Brummell K: Effectiveness of home based support for older people: systematic review and meta-analysis. BMJ 2001, 323(7315):719-725.

13. Landi F, Gambassi G, Pola R, Tabaccanti S, Cavinato T, Carbonin PU, Bernabei R: Impact of integrated home care services on hospital use. J Am Geriatr Soc 1999, 47(12):1430-1434.

14. Stuck AE, Aronow HU, Steiner A, Alessi CA, Bula CJ, Gold MN, Yuhas KE, Nisenbaum R, Rubenstein LZ, Beck JC: A trial of annual in-home comprehensive geriatric assessments for elderly people living in the community. N Engl J Med 1995, 333(18):1184-1189.

15. Bouman A, van Rossum E, Evers S, Ambergen T, Kempen G, Knipschild P: Effects on health care use and associated cost of a home visiting program for older people with poor health status: a randomized clinical trial in the Netherlands. J Gerontol A Biol Sci Med Sci 2008, 63(3):291-297.

16. Huss A, Stuck AE, Rubenstein LZ, Egger M, Clough-Gorr KM: Multidimensional preventive home visit programs for communitydwelling older adults: a systematic review and meta-analysis of randomized controlled trials. J Gerontol A Biol Sci Med Sci 2008, 63(3):298-307.

17. van Haastregt JC, Diederiks JP, van Rossum E, de Witte LP, Crebolder HF: Effects of preventive home visits to elderly people living in the community: systematic review. BMJ 2000, 320(7237):754-758.

18. Fujita T, Mori H, Osaki Y, Minowa M, Ishihara S, Masuda N, Hanzawa Y, Mori C, Nanba T, Ohta H, et al: A case-control study on factors relating to discontinuation of domiciliary care for the bedridden elderly in a metropolitan area. Japanese Journal of Public Health 1992, 39(9):687-695.

19. Watanabe M, Kono K, Kawamura K, Matsuura T: Factors influencing admission to nursing homes among frail and bedridden elderly persons receiving public health and welfare services. Japanese Journal of Public Health 1998, 45(1):45-55.

20. Tajika E, Kikuchi J: Kaigo-hoken niyoru yokaigo-jotai no iji kaizen koka: kohyodeta wo mochiita bunseki (The effect of Long-term Care Insurance for maintaining or improving care dependency level in Japan: Analysis 
using individual data). The Quarterly of Social Security Research 2005, 41(3):248-262.

21. Tajika E, Kikuchi J: What are the Problems with Nursing Insurance? Study on the Process of System Creation and its Effects on Improving States of Nursing Requirement -. Financial Review 2006, 80(March):157-186.

22. Kikuzawa S, Sawai M, Fujiii K, Matsubara C: Effect of service use under long-term care insurance among those with light disability level Analyses of change in disability level using panel data. Japanese Journal of Gerontology 2007, 29(3):375-383.

23. Matsumoto T, Nekoda Y: Zaitaku yoshien yokaigo1 ninteisha ni okeru kaigo-hoken sabisu riyo no kaigodo akka boshi heno koka ni kansuru bunseki (Analysis of the impact of Long-term Care services on preventing functional decline of community-dwelling light-need users (lowest three levels)). Journal of Health and Welfare Statistics 2009, 56(10):20-26.

24. Kato G, Tamiya N, Kashiwagi M, Sato M, Takahashi H: Relationship between home care service use and changes in the care needs level of Japanese elderly. BMC Geriatr 2009, 9(1):58.

25. Gaugler JE, Kane RL, Kane RA, Newcomer R: Early community-based service utilization and its effects on institutionalization in dementia caregiving. Gerontologist 2005, 45(2):177-185.

26. Wimo A, Mattsson B, Adolfsson R, Eriksson T, Nelvig A: Dementia day care and its effects on symptoms and institutionalization: A controlled Swedish study. Scand J Prim Health Care 1993, 11:117-123.

27. Weissert WG, Hedrick SC: Lessons learned from research on effects of community-based long-term care. J Am Geriatr Soc 1994, 42(3):348-353.

28. Kosloski K, Montgomery RJ: The impact of respite use on nursing home placement. Gerontologist 1995, 35(1):67-74.

29. Xu H, Weiner M, Paul S, Thomas J, Craig B, Rosenman M, Doebbeling CC, Sands LP: Volume of home- and community-based Medicaid waiver services and risk of hospital admissions. J Am Geriatr Soc 58(1):109-115.

30. Tsutsui T, Muramatsu N: Care-Needs Certification in the Long-Term Care Insurance System of Japan. J Am Geriatr Soc 2005, 53:522-527.

31. Ikegami N: Rationale, design and sustainability of long-term care insurance in Japanin-retrospect. Soc Policy Soc 2007, 6:423-434

32. Igarashi A, Yamada Y, Ikegami N, Yamamoto-Mitani N: Effect of the Japanese preventive-care version of the Minimum Data Set - Home Care on the health-related behaviors of community-dwelling, frail older adults and skills of preventive-care managers: A quasi-experimental study conducted in Japan. Geriatrics \& Gerontology International 2009, 9(3):310-319.

33. Ikegami N: Impact of public long-term care insurance in Japan. Geriatric and Gerontology International 2004, 4(s1):S146-S148.

34. Campbell JC, Ikegami N: Japan's radical reform of long-term care. Social Policy Administration 2003, 37:21-34.

35. Ikegami N, Campbell JC: Nihon no Iryo-Tosei to Baransu Kankaku (Medical Care in Japan-Control and Sense of Balance). Chuokoronsha 1996, 1314.

36. Japan Geographic Data Center: 2007 Jyumin Kihon Daicho Jinko Yoran (Population summary of basic residents' register). Japan Geographic Data Center; 2007.

37. All-Japan Federation of National Health Insurance Organizations: 2007 Kokumin-Kenko-Hoken no Jittai (Situation of Citizen's Health Insurance). All-Japan Federation of National Health Insurance Organizations, Prefectural National Health Insurance Organizations; 2008.

38. Japan Geographic Data Center: 2002 Jyumin Kihon Daicho Jinko Yoran (Population summary of basic residents' register). Japan Geographic Data Center; 2002.

39. Japan Geographic Data Center: 2008 Jyumin Kihon Daicho Jinko Yoran (Population summary of basic residents' register). Japan Geographic Data Center; 2008.

40. All-Japan Federation of National Health Insurance Organizations: 2003 Kokumin-Kenko-Hoken no Jittai (Situation of Citizen's Health Insurance). All-Japan Federation of National Health Insurance Organizations, Prefectural National Health Insurance Organizations; 2004

41. All-Japan Federation of National Health Insurance Organizations: 2008 Kokumin-Kenko-Hoken no Jittai (Situation of Citizen's Health Insurance). All-Japan Federation of National Health Insurance Organizations, Prefectural National Health Insurance Organizations; 2009.
42. Japan Ministry of Health, Labour and Welfare; Ministry Secretariat; Statistics and Information Department: 2001 Report on the Status of the Longterm Care Insurance Project. Tokyo 2003 [http://www.e-stat.go.jp/SG1/ estat/GL02010101.do].

43. Japan Ministry of Health, Labour and Welfare; Ministry Secretariat; Statistics and Information Department: 2007 Report on the Status of the Longterm Care Insurance Project. Tokyo 2009 [http://www.e-stat.go.jp/SG1/ estat/GL02010101.do].

44. Japan Ministry of Health, Labour and Welfare; Ministry Secretariat; Statistics and Information Department: 2001 Survey of Long-term Care Benefit Expenditures. Japan Health and Welfare Statistics Association 2003.

45. Japan Ministry of Health, Labour and Welfare; Ministry Secretariat; Statistics and Information Department: 2002 Survey of Long-term Care Benefit Expenditures. Japan Health and Welfare Statistics Association 2004.

46. Japan Ministry of Health, Labour and Welfare; Ministry Secretariat; Statistics and Information Department: 2007 Survey of Long-term Care Benefit Expenditures. Japan Health and Welfare Statistics Association 2009.

47. Ohnuki-Tierney E: Illness and culture in contemporary Japan: an anthropological view. New York: Cambridge University Press; 1984.

48. Cohen MA, Tell EJ, Wallack SS: The risk factors of nursing home entry among residents of six continuing care retirement communities. J Gerontol 1988, 43(1):S15-21.

49. Wolinsky FD, Callahan CM, Fitzgerald JF, Johnson RJ: The risk of nursing home placement and subsequent death among older adults. I Gerontol 1992, 47(4):S173-182.

50. Boult C, Dowd B, McCaffrey D, Boult L, Hernandez R, Krulewitch H: Screening elders for risk of hospital admission. J Am Geriatr Soc 1993, 41(8):811-817.

51. Bula CJ, Berod AC, Stuck AE, Alessi CA, Aronow HU, Santos-Eggimann B, Rubenstein $L Z$, Beck JC: Effectiveness of preventive in-home geriatric assessment in well functioning, community-dwelling older people: secondary analysis of a randomized trial. J Am Geriatr Soc 1999, 47(4):389-395.

52. Tomiak M, Berthelot JM, Guimond E, Mustard CA: Factors associated with nursing-home entry for elders in Manitoba, Canada. J Gerontol A Biol Sci Med Sci 2000, 55(5):M279-287.

53. Banaszak-Holl J, Fendrick AM, Foster NL, Herzog AR, Kabeto MU, Kent DM, Straus WL, Langa KM: Predicting nursing home admission: estimates from a 7-year follow-up of a nationally representative sample of older Americans. Alzheimer Dis Assoc Disord 2004, 18(2):83-89.

54. Bharucha AJ, Pandav R, Shen C, Dodge HH, Ganguli M: Predictors of nursing facility admission: a 12-year epidemiological study in the United States. J Am Geriatr Soc 2004, 52(3):434-439.

55. Harris $Y$, Cooper JK: Depressive symptoms in older people predict nursing home admission. J Am Geriatr Soc 2006, 54(4):593-597.

56. Gaugler JE, Duval S, Anderson KA, Kane RL: Predicting nursing home admission in the U.S: a meta-analysis. BMC Geriatr 2007, 7:13.

57. Howell S, Coory M, Martin J, Duckett S: Using routine inpatient data to identify patients at risk of hospital readmission. BMC Health Serv Res 2009, 9:96.

58. O'Connor DW, Pollitt PA, Brook CP, Reiss BB, Roth M: Does early intervention reduce the number of elderly people with dementia admitted to institutions for long term care? BMJ 1991, 302(6781):871-875.

59. Gaugler JE, Edwards AB, Femia EE, Zarit SH, Stephens MA, Townsend A, Greene R: Predictors of institutionalization of cognitively impaired elders: family help and the timing of placement. J Gerontol B Psychol Sci Soc Sci 2000, 55(4):P247-255

60. Gaugler JE, Kane RL, Kane RA, Clay T, Newcomer R: Caregiving and institutionalization of cognitively impaired older people: utilizing dynamic predictors of change. Gerontologist 2003, 43(2):219-229.

61. Lawton MP, Brody EM, Saperstein AR: A controlled study of respite service for caregivers of Alzheimer's patients. Gerontologist 1989, 29(1):8-16.

62. Lee D, Morgan K, Lindesay J: Effect of institutional respite care on the sleep of people with dementia and their primary caregivers. J Am Geriatr Soc 2007, 55(2):252-258.

63. Mann WC, Ottenbacher KJ, Fraas L, Tomita M, Granger CV: Effectiveness of assistive technology and environmental interventions in maintaining independence and reducing home care costs for the frail elderly. A randomized controlled trial. Arch Fam Med 1999, 8(3):210-217. 
64. Kosloski K, Montgomery RJ: The effects of respite on caregivers of Alzheimer's patients: One year evaluation of the Michigan Model Respite Programs. Journal of Applied Gerontology 1993, 12:4-17.

65. Gaugler JE, Jarrott SE, Zarit SH, Stephens MA, Townsend A, Greene R: Respite for dementia caregivers: the effects of adult day service use on caregiving hours and care demands. Int Psychogeriatr 2003, 15(1):37-58.

66. Strain LA, Chappell NL, Blandford AA: Changes in life satisfaction among participants of adult day care and their informal caregivers. J Gerontology Soc Work 1988, 11(3/4):115-129.

67. Kuzuya M, Masuda Y, Hirakawa Y, Iwata M, Enoki H, Hasegawa J, Iguchi A: Day care service use is associated with lower mortality in communitydwelling frail older people. J Am Geriatr Soc 2006, 54(9):1364-1371.

68. Japan Ministry of Health, Labour and Welfare: Kaigo Yobo Shichoson Moderu Jigyo Hokokusho (The Evaluation Report of the Model Projects for Prevention Care in Municipalities). Japan Ministry of Health, Labour and Welfare 2007 [http://www.mhlw.go.jp/topics/kaigo/topics/050727/index. html].

69. Koukouli S, Vlachonikolis IG, Philalithis A: BMC Health Serv Res 2002, 2(1):20

70. Yeh SC, Liu YY: Influence of social support on cognitive function in the elderly. BMC Health Serv Res 2003, 3(1):9.

71. Temkin-Greener H, Meiners MR: Transitions in long-term care. Gerontologist 1995, 35(2):196-206.

72. Okusa Y: Kaigo-hoken no shijo bunseki (Market analysis of Long-term Care Insurance). The Quarterly of Social Security Research 2000, 36(3):338-352.

Pre-publication history

The pre-publication history for this paper can be accessed here: http://www.biomedcentral.com/1472-6963/10/345/prepub

doi:10.1186/1472-6963-10-345

Cite this article as: Tomita et al:: Impact of home and community-based services on hospitalisation and institutionalisation among individuals eligible for long-term care insurance in Japan. BMC Health Services Research 2010 10:345.

\section{Submit your next manuscript to BioMed Central and take full advantage of:}

- Convenient online submission

- Thorough peer review

- No space constraints or color figure charges

- Immediate publication on acceptance

- Inclusion in PubMed, CAS, Scopus and Google Scholar

- Research which is freely available for redistribution

Submit your manuscript at www.biomedcentral.com/submit 